\title{
KEBIJAKAN HUKUM DALAM PENYELESAIAN KEWARISAN ISLAM (Analisis Terhadap Beberapa Kebijakan Umar bin al-Khattab)
}

\author{
Elfia \\ Fakultas Syari' ah Universitas Islam Negeri Imam Bonjol Padang \\ elfiauinib@gmail.com
}

\begin{abstract}
The central point in this study is to analyze some of the legal policies ever made by Umar bin al-Khattab in solving the problem of inheritance. Launched this research to formulate figh of heritage fill the legal policy when difference estoppel happened to adapt to the spirit of the prevailing of justice in society. On legal policy that took by Prophet companions, God bless them in al-Mawarits, it can be informed of a number of issues, as a matter of reliability and Aul and Radd, Gharrawain, Akdariyah, Musyarakah and al-Kharqa'. Stuck legal policy in settling the issue of inheritance justice for all the heirs, because in the settlement of this matter without conditioning will lead to the problem must be resolved patients to win win solution and does not violate the legal argument of the proposition. Took place this issue in the days of Umar bin alKhattab, he judged them around, then signed again in the Supreme Court and he judged it. It seems that the Supreme Court of Indonesia has taken flexibility and adaptability in government policy. Like giving the their of the inheritance hit him with a different religion. Why did Umar bin al-Khattab take a legal policy in solving the inheritance problem? What is the underlying legal policy?Access to data and formulas and find a solution to the problems in this study by using library research, and was done through the relevant issues that have been discussed during data collection. This is a research study on the appropriateness and consistency sentences between theoretical and practical. The approach taken in this study is a qualitative approach in the style of descriptive analysis. It is that some of the policies described in the division of heritage, which spent by the Prophet Companions and scholars (Ulema) of the four schools (Mazhab). The result of your search reveal resolve the issue of inheritance in Islam and settled appropriate to good policy and entrusted interest and do not conflict with a peremptory verses of legal texts. The policies made by Umar bin al-Khattab, in some circumstances are still influenced by the Arab tradition of jahiliyah which requires men to get more rights than women.
\end{abstract}

Keywords : Legal Policy, Inheritance, Umar Bin Al-Khattab

\begin{abstract}
Abstrak
Titik sentral dalam penelitian ini adalah menganalisis beberapa kebijakan hukum yang pernah dibuat oleh Umar bin al-Khattab dalam menyelesaikan masalah kewarisan. Penelitian ini berangkat dari perumusan fikih mawaris itu sendiri yang penuh dengan kebijakan-kebijakan hukum ketika adanya perbenturan hukum dengan hukum, untuk
\end{abstract}

FOKUS : Jurnal Kajian Keislaman dan Kemasyarakatan Vol. 2, No. 2, 2017

P3M Sekolah Tinggi Agama Islam Negeri (STAIN) Curup - Bengkulu

Available online: http://journal.staincurup.ac.id/index.php/JF

p-ISSN 2548-334X, e-ISSN 2548-3358 
mengakomodir rasa keadilan masyarakat. Kebijakan hukum yang dibuat oleh ulama sahabat dalam masalah kewarisan, dapat dilihat dari beberapa bentuk penyelesaian kewarisan seperti dalam masalah 'aul dan radd, gharawain, akdariyah, musyarakah dan al-kharqa'. Kebijakan hukum tersebut didasarkan kepada keadilan untuk semua ahli waris, karena jika dalam pembagian, dalam beberapa kondisi, tetap mengacu kepada pelaksanaan hukum menurut adanya akan menemui kesulitan. Sehingga dalam keadaan seperti ini diperlukan sebuah kebijakan yang dapat diterima oleh semua pihak tanpa melanggar aturan hukum yang mesti dijalankan. Kebijakan hukum seperti beberapa contoh di atas bukan saja berlaku dan pernah dilakukan oleh ulama sahabat seperti Umar bin al-Khattab dan sahabat lainnya. Namun, dalam beberapa putusan yang dikeluarkan oleh Mahkamah Agung, ternyata kebijakan hukum juga telah banyak menjadi solusi dalam penyelesaian kasus yang diajukan ke Mahkamah Agung. Umpamanya Mahkamah Agung memberikan hak kepada ahli waris yang berbeda agama. Kenapa Umar bin al-Khattab mengambil sebuah kebijakan hukum dalam menyelesaikan masalah kewarisan? Apa yang mendasari adanya kebijakan hukum tersebut? Penelitian ini merupakan penelitian kepustakaan (library research), dengan cara mengumpulkan data melalui menelaah bahan-bahan kepustakaan yang relevan dengan masalah yang dibahas. Penelitian ini dapat juga dikategorikan sebagai penelitian normatif tentang sinkronisasi hukum, melihat kesesuaian antara hukum secara teoritis dan praktis. Sedangkan pendekatan yang digunakan dalam penelitian ini adalah pendekatan kualitatif dengan metode deskriptif analisis yaitu dengan memaparkan beberapa kebijakan hukum pembagian warisan dalam hukum kewarisan Islam yang dapat ditemukan dalam beberapa kasus kewarisan dan pernah diselesaikan pada zaman sahabat dan ulama mazhab. Hasil penelitian ini mengungkapkan bahwa dalam penyelesaian pembagian warisan dalam Islam dapat ditempuh kebijakan hukum selama kemashlahatan menghendakinya dan tidak menyalahi dalil-dalil yang qath'i dalam al-Qur'an dan Hadis. Adapun kebijakan yang dibuat oleh Umar bin al-Khattab, dalam beberapa kondisi masih dipengaruhi oleh tradisi arab jahiliyah yang mengharuskan laki-laki mendapatkan hak lebih dari perempuan.

Kata Kunci : Kebijakan Hukum, Kewarisan, Umar bin al-Khattab

\section{PENDAHULUAN}

Rasa keadilan masyarakat menghendaki sesuatu hukum, tetapi pembuat hukum tidak siap menerima rasa keadilan masyarakat itu. Sesuatu yang baik dianggap oleh masyarakat itu belum bisa diterima pembuat kebijakan hukum karena berbenturan dengan Undang-undang yang lebih tinggi. Pada saat itulah muncul kebijakan hukum sebagai solusi untuk menjembatani kehendak masyarakat atau umat berdasarkan keadilan menurut pembuat hukum. Contoh sebuah kebijakan hukum yang terjadi di dunia Islam adalah keputusan Mahkamah Agung tentang ahli waris yang berbeda agama. Hukum mengatakan bahwa ahli waris yang berbeda agama tidak menerima warisan karena ahli waris berbeda agama 
itu menurut hukum yang digunakan menyalahi syarat yang ditetapkan oleh hadis Nabi SAW. Namun untuk mengubah hal itu dengan cepat tidak mungkin, karena akan terjadi penolakan oleh umat Islam jika orang yang berbeda agama itu dinyatakan akan menerima warisan sebagaimana ahli waris yang lain. Di samping itu rasa keadilan masyarakat juga menuntut ahli waris yang berbeda agama itu mendapat bagian dalam harta warisan dan menuntut ketentuan hukum itu dijadikan Undang-undang. Akan tetapi jika itu dijadikan hukum akan berbenturan dengan hukum yang lebih tinggi yaitu hukum Islam. Sebagai solusi untuk memenuhi rasa keadilan masyarakat tanpa menyalahi Undang-undang (hukum yang lebih tinggi) dan tanpa berlawanan dengan prinsip yang tidak mungkin dirubah maka Mahkamah Agung mengeluarkan keputusan bahwa mereka diberi hak dari harta peninggalan tetapi tidak dalam bentuk warisan. Dengan soluisi seperti ini semua pihak merasa menang. Yang menuntut persamaan hak merasa menang dan yang tetap mengatakan terhalang juga merasa menang karena tidak ada yang terlanggar. Bentuk kebijakan hukum seperti ini merupakan putusan yang bisa diterima semua pihak, dan semua pihak merasa menang.

Contoh lain yang berkenaan dengan warisan adalah cucu yang ayahnya meninggal lebih dahulu dalam ketentuan fikih ia tidak dapat menerima warisan. Alasannya karena ia terhijab oleh anak atau saudara dari ayah pewaris. Namun rasa keadilan menuntut bahwa ia sangat pantas menerima hak dari harta warisan sebagai pengganti ayahnya. Maka diupayakan sebuah cara atau solusi dengan tidak mengubah ketentuan Undang-undang namun rasa keadilan masyarakat dapat tertampung di dalamnya. Salah satu bentuk yang dilakukan mujtahid adalah dengan memberikan wasiat wajibah untuk cucu tersebut. Inilah yang dinamakan dengan sebuah kebijakan, karena mujhatid belum berani menempatkan cucu di sini sebagai ahli waris yang berhak disebabkan ia termasuk ahli waris yang mahjub.

Contoh lain lagi dalam masalah wasiat wajibah. Orang tua dan anak angkat menurut ketentuan hukum Islam tidak berhak menerima warisan, karena tidak memenuhi sebab-sebab hubungan kewarisan. Tetapi dalam kasus tertentu siapapun akan mengatakan bahwa anak angkat atau orang tua angkat itu mesti menerima pembagian dari harta yang ditinggalkan pewaris. Kalau yang diberikan adalah harta warisan dalam arti mereka dinyatakan ahli waris yang sah maka hal itu melangar hukum. Oleh karena itu digunakanlah kebijakan hukum dengan memberikan harta 
kepada mereka dalam bentuk wasiat bukan dengan nama warisan. Pemberian dengan nama wasiat tersebut karena sifatnya ikhtiari bukan ijbari (disebabkan ada yang sempat melakukan wasiat dan ada juga yang tidak). Oleh karena itu untuk menggungkapkan hal itulah adanya wasiat wajibah. Walaupun sifatnya adalah kebijakan hukum tetapi formatnya sudah dalam bentuk Undang-undang. Penggunaan Undang-undang itu sendiri adalah kebijakan hukum. ${ }^{1}$

Perumusan fikih mawaris penuh dengan kebijakan hukum ketika adanya perbenturan hukum dengan hukum, untuk mengakomodir rasa keadilan masyarakat. Kebijakan hukum yang dibuat oleh ulama sahabat dalam masalah kewarisan, dapat dilihat dari beberapa bentuk penyelesaian kewarisan seperti dalam masalah 'aul dan radd, gharawaian, akdariyah, musyarakah, dan al-kharqa'. Kebijakan hukum seperti beberapa contoh di atas bukan saja berlaku dan pernah dilakukan oleh ulama sahabat seperti Umar bin al-Khattab dan sahabat lainnya. Namun dalam beberapa putusan yang dikeluarkan oleh Mahkamah Agung, ternyata kebijakan hukum juga telah banyak menjadi solusi dalam menyelesaikan kasus yang diajukan ke Mahkamah Agung. Dalam tulisan ini, masalah yang menjadi titik sentral adalah kenapa Umar bin al-Khattab menggunakan kebijakan hukum dalam menyelesaikan masalah kewarisan? Apakah kebijakan hukum yang dibuat oleh Umar bin alKhattab tidak menyalahi ketentuan nash dalam bidang kewarisan? Apakah dasar yang dijadikan Umar bin al-Khattab menggunakan kebijakan hukum dalam menyelesaikan masalah kewarisan?

${ }^{1}$ Contoh yang terjadi di dunia Islam juga adalah dalam masalah pencatatan perkawinan dan batas usia dalam pernikahan. Dalam ketentuan hukum Islam tidak ada pencatatan perkawinan dan tidak ada batas umur perkawinan. Dua ketentuan ini tidak diatur di dalam fikih. Namun rasa keadilan masyarakat (kemashlahatan) menuntut perkawinan itu harus dicatat dan yang akan kawin itu harus memenuhi batas usia yaitu telah dewasa. Jika dibuat Undang-undang tentang dipersyaratkan adanya pencatatan perkawinan dan dipersyaratkan adanya batas usia perkawinan berarti akan menimbulkan keberatan-keberatan di kalangan ulama fikih. Cara mengatasi hal tersebut, bukan dengan cara membuat Undang-undang secara langsung tetapi dibuat Peraturan Pemerintah: 1. Sengketa perkawinan tidak boleh diselesaikan di wilayah Pengadilan Agama kecuali perkawinannya itu tercatat oleh instansi resmi; 2. Pencatat perkawinan (KUA) tidak boleh mengeluarkan surat terjadinya perkawinan itu bila pengantin tidak memenuhi ketentuan batas umur perkawinan. Dengan dua ketentuan yang didasarkan kepada Peraturan Pemerintah tersebut itulah yang dinamakan dengan kebijakan hukum sebagai solusi menjawab dua permasalahan di atas. Kebijakan tersebut tidak mengubah Undangundang namun secara praktis telah terlaksana. 
Sejauh ini penelitian yang membahas tentang hukum kewarisan Islam sudah dilakukan oleh peneliti-peneliti lain, namun objek penelitian yang telah ada bukan mengenai objek yang penulis teliti. Di antaranya: Pertama, penelitian yang dilakukan oleh Amir Syarifuddin yang menyimpulkan bahwa pelaksanaan hukum waris Islam dalam masyarakat Minangkabau sangat kental dengan nuansa kekeluargaan dan kekerabatan. Namun kekhususannya terletak pada corak garis keturuanan ibu (matrilineal) dalam praktek pembagian harta warisan. ${ }^{2}$ Kedua, penelitian oleh Ali Yasa Abu Bakar yang menyimpulkan bahwa ijtihad Hazairin telah menciptakan sebuah sistim yang lebih padu dan menyeluruh, yakni melalui pendekatan antropologi telah membuka peluang menafsirkan yata-ayat kewarisan dalam kerangka yang lebih luas. ${ }^{3}$ Ketiga, oleh Umar Syihab, penelitian ini menggunakan pendekatan teologis, osiologis dan normatif. Penelitian ini menyimpulkan bahwa penerimaan syara'oleh sistim Hukum Adat Bugis Wajo "Pangadereng" telah melahirkan pelaksanaan hukum Kewarisan Islam di Wajo. ${ }^{4}$ Keempat, penelitian oleh Neng Djubaedah, Ia menyimpulkan bahwa pelaksanaan hukum waris Islam dalam masyarakat Pandeglang sangat kental dengan nuansa kekeluargaan dan kekerabatan. Meskipun hukum Islam menjadi hukum yang hidup dan berlaku di masyarakat, namun praktek pembagian harta warisan umumnya banyak diselesaikan melalui musyawarah antara anggota keluarga atau ahli waris. ${ }^{5}$ Kelima, penelitian yang ditulis oleh Surwati membahas tentang "Problematika Hukum Kewarisan di Pengadilan Agama Padang”. Penelitian ini meneliti beberapa kasus kewarisan yang terjadi di Pengadilan Agama Padang, tentang penetapan hak ahli waris. Sedangkan dalam penelitian ini difokuskan pada kajian tentang kebijakan dalam hukum kewarisan Islam,

${ }^{2}$ Amir Syarifuddin, "Pelaksanaan Hukum Kewarisan Islam dalam Lingkungan Adat Minangkabau”, disertasi pada Program Pascasarjana IAIN Syarif Hidayatullah Jakarta, 1982.

${ }^{3}$ Ali Yasa Abu Bakar, "Ahli Waris Sepertalian Darah : Kajian Perbandingan Terhadap Penelaran Hazairin dan Penalaran Fikih Mazhab”, disertasi pada Program Pascarajana IAIN Sunan Kalijaga Jakarta, 1996.

${ }^{4}$ Umar Syihab, "Hukum Kewarisan Islam dan Pelaksanaannya di Wajo", disertasi pada Program Pascasarjana IAIN Sultan Alaudin Makasar, 1996.

${ }^{5}$ Neng Djubaedah, "Pelaksanaan Hukum Waris Islam di Kabupaten Pandeglang Banten”, tesis pada Program Pascasarjana Universitas Indonesia (UI), 2005. 
dengan menganalisis beberapa kebijakan Umar bin al-Khattab dalam penyelesaian kewarisan. ${ }^{6}$

Metode yang digunakan dalam pemecahan permasalahan penelitian ini adalah dengan penelitian kepustakaan (library research). Penelitian kepustakaan dilakukan dengan cara mengumpulkan data melalui menelaah bahan-bahan kepustakaan yang relevan dengan masalah yang dibahas. ${ }^{7}$ Penelitian ini dapat juga dikategorikan sebagai penelitian normatif tentang sinkronisasi hukum. Artinya, penelitian yang melihat kesesuaian antara hukum secara teoritis dan praktis. Pendekatan yang digunakan adalah pendekatan kualitatif dengan metode deskriptif analisis, yaitu dengan memaparkan beberapa kebijakan hukum pembagian warisan dalam Hukum Kewarisan Islam yang dapat ditemukan dalam beberapa kasus kewarisan yang pernah diselesaikan pada zaman sahabat dan ulama mazhab. Pada penelitian kepustakaan atau penelitian normatif, data yang digunakan adalah data sekunder. ${ }^{8}$ Jenis data yang digunakan dalam penelitian ini adalah data sekunder. Data sekunder terdiri dari bahan hukum primer, bahan hukum sekunder. Setelah data yang dibutuhkan terkumpul, lalu dianalisa dengan metode Content Analysis (Analisis terhadap Isi), atau sering pula disebut sebagai analisis isi atau dokumen.

Kajian terkait dengan kebijkan hukum dalam penyelesaian kewarisan ini bertujuan untuk mengungkap, mengetahui dan menganalisis beberapa kebijakan hukum yang pernah dibuat oleh Umar bin al-Khattab di antaranya untuk mengetahui kenapa Umar menggunakan kebijakan hukum dalam menyelesaikan masalah kewarisan. Juga untuk mengetahui apakah kebijakan hukum yang dibuat oleh Umar bin al-Khattab itu tidak menyalahi nash yang ada dan apa yang menjadi dasar yang digunakan Umar dalam menggunakan kebijkan hukum tersebut.

\section{PEMBAHASAN \\ Pengertian Kebijakan Hukum}

Istilah "kebijakan hukum" merupakan rangkaian kata yang terdiri dari kata "kebijakan" dan "hukum". Dalam istilah hukum, kebijakan

\footnotetext{
${ }^{6}$ Surwati, "Problematika Hukum Kewarisan di Pengadilan Agama Padang", tesis pada Program Pascasarjana IAIN Imam Bonjol Padang, 2005.

${ }^{7}$ Soerjono Soekanto dan Sri Mamudji, Penelitian Hukum Normatif: Suatu Tinjauan Singkat, (Jakarta: PT. Rajagrafindo Persada, 1983), hlm. 13-14

${ }^{8}$ Ibid.,hlm. 24
} 
(policy) adalah istilah yang tampaknya telah disepakati bersama. Kata "kebijakan" berasal dari kata "bijak" yang arti dasarnya adalah selalu menggunakan akal budi, pandai dan mahir. Adapun ketika kata "bijak" diberi awalan "ke" dan akhiran "an" menjadi "kebijakan" secara etimologi berarti kepandaian, kemahiran, kebijaksanaan. Dalam pengertian yang lebih sempuna lagi kebijakan berarti rangkaian konsep dan asas yang menjadi pedoman dan dasar rencana dalam pelaksanaan suatu pekerjaan, kepemimpinan dan cara bertindak, yang dapat diterapkan pada pemerintahan, organisasi, kelompok sektor swasta atau individu; juga dapat berarti pernyataan cita-cita, tujuan, prinsip, atau maksud sebagai garis pedoman untuk manajemen dalam usaha mencapai sasaran atau garis haluan. ${ }^{9}$ Inilah yang membedakan kebijakan dengan peraturan dan hukum. Jika hukum dapat memaksakan atau melarang suatu perilaku (misalnya suatu hukum yang mengharuskan pembayaran pajak penghasilan), kebijakan hanya menjadi pedoman tindakan yang paling mungkin memperoleh hasil yang diinginkan. Kebijakan dapat berbentuk keputusan yang dipikirkan secara matang dan hati-hati oleh pengambil keputusan puncak dan bukan kegiatan-kegiatan berulang yang rutin dan terprogram atau terkait dengan aturan-aturan keputusan. Kebijakan dapat pula merujuk pada proses pembuatan keputusan-keputusan organisasi, termasuk identifikasi berbagai alternatif pemilihannya berdasarkan dampaknya untuk mencapai suatu tujuan eksplisit. ${ }^{10}$

Dari beberapaa definisi "kebijakan" dan "hukum" yang dikemukakan oleh para ahli di atas dapat dirumuskan bahwa "kebijakan hukum" adalah serangkaian konsep dan asas yang menjadi pedoman untuk melakukan tindakan guna memecahkan atau menyelesaikan permasalahan yang tidak mungkin diselesaikan dengan hanya berpegang kepada hukum karena adanya hambatan-hambatan tertentu. Sebelum ia masuk ke dalam pasal hukum maka disebut dengan kebijakan hukum, akan tetapi jika ia telah menjadi sebuah pasal hukum maka tidak lagi dinamakan kebijakan hukum. Adanya kebijakan hukum ini dilakukan untuk mencapai tujuan tertentu dan sasaran yang diinginkan.

${ }^{9}$ Sudarsono, Kamus Hukum, (Jakarta: Rineka Cipta, 2005), cet. ke-4, hlm. 57-58. Lihat juga Depeartemen Pendidikan dan Kebudayaan, Kamus Besar Bahasa Indonesia, (Jakarta: Balai Pustaka, 1990), cet. Ke-3, hlm. 115.

${ }^{10}$ Sering diperdebatkan apa perbedaan antara kebijakan dengan kebijaksanaan. Ini terjadi, karena dua kata ini, kebijakan dan kebijaksanaan, sama-sama belum dibakukan ke dalam bahasa Indonesia. Dalam pengertian, kedua kata ini masih belum disepakati penggunaannya. 
Berdasarkan rumusan kebijakan hukum sebagaimana yang telah dijelaskan sebelumnya dapat dirumuskan juga beberapa prinsip dan atau karakteristik dari sebuah kebijakan hukum, di antaranya :

1. Kebijakan hukum yang diambil itu berada dalam masalah ijtihadiyah. Dalam masalah yang bukan merupakan lapangan ijtihad maka tidak berlaku adanya kebijakan hukum;

2. Kebijakan hukum itu tidak bertentangan dengan prinsip hukum atau dengan hukum yang kedudukan hukumnya lebih tinggi;

3. Kebijakan hukum bersifat mengkompromikan antara kepentingan dan keinginan yang berbeda;

4. Setelah kebijakan hukum diterima oleh pembuat hukum maka kebijakan hukum itu tidak diperlukan lagi. Jadi, kebijakan hukum itu menunggu kesedian hukum untuk menerima menjadi hukum (sifatnya sementara);

5. Mempunyai kebijakan berarti memiliki alasan atau argumen yang mengandung klaim bahwa pemilik kebijakan memahami persoalan berserta solusinya. Kebijakan mengemukakan apa yang sedang terjadi dan apa yang seharusnya dilakukan. Sebuah kebijakan memberikan semacam teori yang mendasari klaim legitimasi;

6. Dalam masyarakat yang tidak terlalu terikat oleh nilai-nilai agama, politisi sebagai pembuat kebijakan membuat sebuah kebijakan berdasarkan pertimbangan rasional atas fakta-fakta;

7. Kebijakan bukan sekedar menghasilkan efek perubahan dalam kondisi masyarakat, kebijakan juga menyatukan orang lain dan mempertahankan ketertiban negara. Misalnya, sebuah kebijakan pemerintah untuk memerangi kemiskinan mungkin tidak akan berdampak signifikan bagi si miskin tetapi ini membuat orang bermoral, orang kaya dan orang miskin berpandangan bahwa pemerintah memperhatikan orang miskin. ${ }^{11}$

\section{Sebab dan Alasan Adanya Kebijakan Hukum}

Adanya sebuah kebijakan hukum memiliki sebab dan alasan tertentu yang menimbulkan perubahan dalam ketentuan yang telah ada. Sebab dan alasan tersebut di antaranya: 1. membuat kebijakan hukum untuk melakukan perubahan hukum yang berlaku (ius constitutum) menjadi

\footnotetext{
${ }^{11}$ Wayne Persons, Persons, Wayne, Public Policy: Pengantar Teori dan Praktik Analisis Kebijakan, (Jakarta : Kencana, 2014), Cet.ke-5, hlm. 614
} 
hukum yang seharusnya (ius constituendum) dalam rangka memenuhi perubahan kehidupan dalam masyarakat. Hukum yang telah berlaku dianggap tidak dapat memenuhi perubahan yang terjadi dalam masyarakat. Secara jelasnya dapat dikatakan bahwa kebijakan itu dilakukan ketika berbenturan dengan yang umum atau yang lazim; 2. kebijakan dibuat karena adanya kesukaran yang timbul dalam melaksanakan hukum yang ada. Kesukaran itu terjadi ketika adanya ketidaksesuaian antara ketentuan hukum yang telah ditetapkan atau yang harus dilakukan dengan kenyataan kehidupan masyarakat yang dihadapi; 3. adanya perbenturan antara menetapkan hukum berdasarkan ketentuan yang berlaku dengan rasa keadilan masyarakat yang sudah berlaku. Hukum pada saat itu berdasarkan tuntutan. Rasa keadilan masyarakat juga harus begitu. Tetapi berdasarkan itu tidak mungkin karena berbenturan dengan kedudukan hukum yang lebih tinggi. Untuk mempertemukan dua hal itulah alasan adanya kebijakan hukum.

\section{Beberapa Kebijakan Umar Bin Al-Khathab dalam Menyelesaikan Masalah Kewarisan.}

Uraian dalam pendahuluan di atas merupakan gambaran dari beberapa bentuk kebijakan hukum yang pernah dibuat oleh pembuat hukum atau mujtahid sebagai sebuah solusi untuk menjawab permasalahan yang timbul disebabkan adanya perbenturan antara ketentuan hukum dengan keadaan yang ada dalam kenyataan. Artinya, baik di dunia Islam atau di luar Islam kebijakan hukum telah digunakan juga oleh para pembuat hukum atau para mujtahid sebelumnya. Contoh praktis yang terjadi di dunia Islam adalah keputusan Mahkamah Agung tentang ahli waris yang berbeda agama. Hukum menyatakan bahwa ahli waris yang berbeda agama tidak mendapatkan harta warisan karena menyalahi syarat yang ditetapkan hadis Nabi SAW. Namun untuk merubah hal itu dengan cepat, tidak mungkin karena akan terjadi penolakan oleh umat Islam, jika orang yang berbeda agama itu dinyatakan akan menerima harta warisan sebagaimana ahli waris lain. Di samping itu, rasa keadilan masyarakat juga menuntut ahli waris yang berbeda agama ini mendapat bagian dalam harta warisan dan menuntut ketentuan hukum itu dijadikan undang-undang. Akan tetapi jika itu dijadikan hukum, akan berbenturan dengan hukum yang lebih tinggi yaitu hukum Islam .Sebagai solusi untuk memenuhi rasa keadilan masyarakat tanpa menyalahi undang-undang (hukum yang lebih tinggi) dan tanpa 
berlawanan dengan prinsip yang tidak mungkin diubah, maka Mahkamah Agung mengeluarkan keputusan bahwa mereka diberi hak dari harta peninggalan tetapi tidak dengan nama warisan.Dengan kebijakan hukum ini, merupakan putusan yang bisa diterima semua pihak dan semua merasa menang.

Contoh lain, seperti yang ditetapkan di Mesir berkenaan dengan warisan cucu yang ayahnya lebih dahulu meninggal. Dalam ketentuan fikih, cucu tersebut tidak dapat menerima warisan karena ia terhijab oleh anak atau saudara dari ayah pewaris. Namun rasa keadilan menuntut bahwa ia sangat pantas menerima hak dari harta warisan sebagai pengganti ayahnya. Sehingga diupayakan sebuah cara atau solusi dengan tidak merubah ketentuan undang-undang namun rasa keadilan masyarakat dapat tertampung di dalamnya. Salah satu bentuk yang dilakukan mujtahid adalah dengan memberikan wasiat wjibah untuk cucu tersebut. Inilah yang dinamakan sebuah kebijakan, karena mujtahid belum berani menenpatkan cucu di sini sebagai ahli waris yang berhak disebabkan ia termasuk ahli waris yang mahjub.

Demikian juga halnya dalam persoalan orang tua angkat dan anak angkat. Menurut ketentuan hukum Islam, orang tua dan anak angkat tidak berhak menerima warisan karena tidak memenuhi sebab-sebab hubungan kewarisan. Tetapi dalam kasus tertentu, siapapun akan mengatakan bahwa anak angkat atau orang tua angkat ini mesti menerima pembagian harta yang ditinggalkan pewaris. Kalau yang diberikan harta warisan dalam arti mereka dinyatakan sebagai ahli waris yang sah, maka hal itu melanggar hukum. Oleh karena itu, digunakan kebijakan hukum dengan memberikan harta kepada mereka dalam bentuk wasiat bukan dengan nama warisan.

Demikian juga halnya dalam penyelesaian beberapa persoalan kewarisan yang termasuk masalah ijtihadiyah, yang lebih bersifat tathbiqy (penerapan hukum) dan dalam penerapannya perlu memperhatikan dan mempertimbangkan niai-nilai keadilan yang hidup dalam kesadaran hukum masyarakat di mana hukum tersebut dilaksanakan, juga memerlukan kebijakan hukum. Di antara masalah penyelesaian warisan yang bersifat ijtihadiyah, yaitu masalah yang diselesaikan menyimpang dari ketentuan yang berlaku secara umum, dengan mengambil kebijakan tertentu yang disebabkan alasan tertentu pula di antaranya:

1. Kebijakan hukum ketika terjadi perbenturan antara tuntutan suatu ketentuan dengan kenyataan yang berlaku (dengan keadaan yang berlaku menurut kenyataan) 
Dalam menyelesaikan pembagian harta warisan ada kemungkinankemungkinan yang dapat terjadi. Apabila dalam suatu kasus pembagian warisan ahli waris hanya terdiri dari dzaul furudh saja, ada tiga kemungkinan yang terjadi, di antaranya:

Bagian yang diterima ahli waris tepat persis dengan harta warisan yang dibagi. Jika terjadi pembagian warisan seperti ini, tidak menimbulkan permasalahan karena jumlah furudh tersebut sama banyak dengan jumlah harta warisan, sehingga setelah diadakan pembagian warisan, setiap ahli waris yang berhak atas furudhnya telah mendapatkan haknya sesuai dengan furudh itu dan harta warisan pun terbagi habis. Dalam sebuah contoh kasus kewarisan, ahli waris yang ada suami (duda) dengan furudh 1/2, ibu dengan furudh $1 / 3$ dan seorang saudara seibu dengan furudh 1/6. Jumlah keseluruhan furudh adalah 6/6, sedangkan harta warisan juga berjumlah 6/6.

Terjadi kekurangan harta ketika bagian dzaul furudhmuqaddarah dilaksanakan apa adanya. Hal ini terjadi ketika furudh itu lebih besar dari keadaan harta warisan sehingga setelah diadakan pembagian, harta warisan sudah habis, sedangkan ahli waris masih ada yang belum mendapatkan haknya sesuai dengan furudh yang mesti ia terima. Permasalahan seperti ini dikenal dengan 'aul.

Terjadi kelebihan harta karena ahli waris dzaul furudh hanya sedikit sedangkan bagian penerimaannya juga sedikit. Ketika dijumlahkan furudh lebih sedikit dari persediaaan harta warisan, sehingga setelah masing-masing mengambil hak sesuai dengan furudhnya, harta masih bersisa. Persolan ini dinamakan dengan radd. ${ }^{12}$

Dalam contoh yang dikemukakan di atas, tidak ada permasalahan yang timbul dalam bentuk pertama karena jumlah harta dan pembagian seimbang. Namun dalam bentuk kedua dan ketiga, para ulama menghadapi masalah bagaimana mencukupkan harta pada bentuk kedua dan akan dikemanakan kelebaihan harta dalam bentuk ketiga. Dua permasalahan terakhir akan diuraikan dalam pembahasan khusus tentang kekurangan dan kelebihan harta warisan.

a. Masalah 'Aul

'Aul secara lughah berarti curang, zalim, dan melampaui batas.

Secara istilah 'aul berarti adanya tambahan dalam kumpulan saham

\footnotetext{
${ }^{12}$ Amir Syarifuddin, Hukum Kewarisan Islam, (Jakarta : Kencana, 2004), hlm. 95-
} 96. 
dari asal masalah atau adanya kekurangan yang terjadi dalam bagian ahli waris. ${ }^{13}$ Masalah " $a u l$ terjadi karena jumlah furudh dari beberapa orang ahli waris yang terkelompok pada satu kasus ternyata melebihi harta yang ada dengan arti harta tidak mencukupi untuk memenuhi furudh-furudh tersebut. Dalam contoh kasus ahli waris adalah saudara perempuan dengan furudh $1 / 2$; suami dengan furudh $1 / 2$ dan ibu dengan furudh 1/3. Furudh-furudh tersebut adalah pasti karena begitu yang disebutkan dalam al-Quran. Namun dalam susunan seperti ini jumlah furudh akan menjadi $1 / 2+1 / 2+1 / 3=3 / 6+2 / 6=8 / 6$. Dalam kasus tersebut ada kekurangan harta sebanyak $2 / 6$. Kalau dibagikan secara langsung berurutan dari saudara perempuan dan suami, harta telah habis sedangkan ibu yang berhak mendapat $1 / 3$ tidak mendapatkan apa-apa. Hal tersebut menyalahi ketentuan faraid. Kalau kekurangan itu dibebankan secara merata kepada semua ahli waris, pasti jumlah furudh yang akan diterimanya, tidak sesuai dengan furudh yang ditentukan. Hal ini menyalahi ketentuan furudh pula.

Bentuk perbenturan yang ada dalam masalah 'aul adalah bahwa menurut ketentuan hukum ahli waris itu diberi hak sesuai dengan hak yang telah ditetapkan. Jika dalam menyelesaikan pembagian harta warisan, terdapat beberapa ahli waris $d z u l$ furudh, maka seluruh furudh-furudh itu harus dijumlahkan. Ternyata dalam penjumlahan itu, dalam keadaan yang tidak bisa ditentukan, jumlah furudh melebihi dari jumlah harta yang ditentukan, dalam arti harta itu tidak terbagi habis dan beberapa ahli waris belum atau tidak menerimanya sesuai dengan yang ditentukan. Inilah yang terjadi dalam kenyataan, karena pemberian hak waris kepada ahli waris itu secara perorangan. Pada saat inilah ditemukan persoalan adanya kekurangan harta dalam penyelesaian pembagian warisan dan dari mana akan diambil kekurangan tersebut. Kalau seandainya diambilkan dari ahli waris yang ada, dengan mengurangi hak mereka yang ada maka mereka akan menerima hak waris tidak sesuai dengan apa yang telah ditetapkan al-Qur'an dan hadis. Dalam al-Qur'an hak waris yang ada itu adalah $1 / 6$, tidak ada yang menerima 1/7, 1/9, 1/13 dan lainnya. Namun jika tidak dilakukan 'aul juga tidak bisa diselesaikan pembagian warisan itu. Dalam

${ }^{13}$ Wahbah al-Zuhaily, al-Fiqh al-Islamy wa Adillatuhu, (Damsyiq: Dar al-Fikr, 1997), Juz.10, hlm. 7819 
kondisi yang serba salah inilah yang menyebabkan adanya perbenturan antara menjalankan ketentuan yang telah ada dengan keadaan yang berlaku dalam kenyataan. Tidak ada jalan lain yang ditempuh oleh ulama selain mengambil kebijakan. Akan tetapi karena kebijakan itu didasarkan kepada ijtihad dan ijtihad ulama itu juga berbeda-beda maka kebijakan yang dihasilkan juga berbedabeda.

Dalam menghadapi masalah ini Umar ibn al-Khattab sebagai seorang sahabat yang pertama menggunakan teori ini, menetapkan kebijakan hukum bahwa kekurangan kadar harta itu dibebankan kepada masing-masing yang berhak berdasarkan kadar perbandingan furudh mereka sehingga hak mereka menjadi berkurang secara adil. Kekurangan saham masing-masing terjadi karena asal masalah atau penyebut pecahannya menjadi meningkat. Meningkatkan asal masalah itu disebut dengan istilah "aul. ${ }^{14}$ Kebijakan hukum yang diambil oleh Umar ibn al-Khattab ini diikuti oleh mayoritas ahli fikih yang disebut jumhur ulama. ${ }^{15}$

Adapun Ibn Abbas mengemukakan kebijakan hukum yang berbeda dengan Umar ibn al-Khattab. Menurut Ibn Abbas, Umar mengambil kebijakan seperti itu karena Umar tidak tahu bagaimana cara mengatasi kekurangan saham, yang kalau dibagikan secara berurutan yang belakangan tidak akan mendapat. Seandainya Umar mengetahui siapa di antara ahli waris itu yang harus didahulukan dan siapa yang dikemudiankan tentu tidak akan ada masalah. ${ }^{16}$

Kebijakan hukum yang dikemukakan oleh Ibn Abbas dalam menyelesaikan masalah di atas, agar tidak terjadi 'aul, adalah dengan menjelaskan bahwa di antara ahli waris itu ada yang harus didahulukan dan dikemudiankan. Prioritas ini ditentukan oleh keadaan ahli waris itu sendiri. Orang-orang yang harus didahulukan adalah ahli waris yang hanya mendapatkan furudh tertentu dan tidak

${ }^{14}$ Ibn Abidin, Hasyiyah Radd al-Mukhtar 'ala ad-Durr al-Muhtar, (Mesir: Mustafa al-Babiy al-Halabiy,1966), Jil.VI, hlm.786

${ }^{15}$ Amir Syarifuddin, Permasalahan dalam Pelaksanaan Faraid, (Padang:IAIN IB Press, 1999),Cet.ke-1, hlm.62. Ada pendapat yang mengatakan bahwa "aul itu merupakan kebijakan yang berasal dari Zaid Ibn Tsabit yang kemudian diikuti oleh Umar. Ada pula yang mengatakan berasal dari Ali. Namun yang jelas, penyelesaian secara " aul itu itu dijalankan oleh jumhur ulama termasuk imam mujtahid yang berempat bahkan ada yang menukilkan yang demikian telah menjadi ijma' ulama.

${ }^{16}$ Ibid., hlm. 20 
ada kemungkinan berubah menjadi asabah. Sedangkan yang harus dikemudiankan adalah ahli waris furudh yang dapat menjadi ashabah waktu mewarisi bersama saudara laki-lakinya. Dalam kasus contoh tersebut di atas, yang didahulukan adalah suami yang mendapat $1 / 2$ dan Ibu yang mendapat $1 / 3$. Kemudian baru diberikan kepada saudara yang akan mendapat seberapa yang tinggal karena seandainya ia didampingi oleh saudaranya yang laki-laki ia tidak akan dapat lebih dari itu. ${ }^{17}$

Memperhatikan perbedaan kebijakan yang diambil ini dengan cermat terlihat bahwa sumber permasalahan ini adalah perbenturan dua prinsip yaitu "tuntutan suatu ketentuan" dengan"keadaan yang berlaku menurut kenyataan". Kebijakan hukum yang diambil Jumhur berpegang kepada prinsip keadilan menurut keadaan yang berlaku menurut kenyataan meskipun apa yang diterima ahli waris sesudah pelaksanaan 'aul itu tidak sebagaimana furudh yang seharusnya, yang berarti menyalahi ketentuan hukum namun kekurangan telah ditanggung bersama secara adil. Sedangkan kebijkan hukum yang diambil Ibn Abbas yang kemudian diikuti oleh golongan Zahiri mengambil prinsip menjalankan tuntutan ketentuan hukum yaitu masing-masing menerima bagian sesuai dengan furudh, meskipun tidak adil karena ada ahli waris tertentu yang tidak menerima menurut semestinya. ${ }^{18}$

Penyelesaian secara "aul ini dapat disebut sebagai masalah dalam arti yang sebenarnya kerana apapun cara yang akan ditempuh tetap berbenturan atau berlainan dari petunjuk yang ada. Kalau digunakan secara teori " $a u l$ maka ahli waris akan menerima hak tidak menurut furudhnya semula. Kalau diikuti kebijakan Ibn Abbas memang beberapa orang yang mendapatkan giliran pembagian dahulu dapat menerima furudhnya yang ditentukan, namun yang dapat giliran kemudian tidak mendapatkan bagian menurut semestinya. Artinya, keadilan dalam teori ini tidak berlaku bagi ahli waris yang diakhirkan penerimaan furudhnya.

Keputusan atau ijtihad Umar bin Khattab terhadap masalah 'aul ini adalah sebuah kebijakan hukum yang ia ambil dalam

${ }^{17}$ Ibn Hazm, al-Muhalla, (Mesir: Mathba'ah al-Jumhuriyah,al-'Arabiyah, 1970), Jilid X, hlm. 332-334

18 Amir Syarifuddin, Hukum Kewarisan Islam, (Jakarta: Kencana, Prenada Media,2004), Edisi.I, Cet.I, hlm.100 
kedudukannya sebagai khalifah. Pada dasarnya ijtihad itu adalah kebijakan, di samping kesimpulan suatu hukum. Dasar kebijakan yang diambil Umar dalam masalah 'aul di atas adalah mempertimbangkan di antara dua hal, mana yang paling menguntungkan dan paling tinggi kemashlahatannya. Tidak salah digunakan kebijakan atau ijtihad Umar itu, sekalipun menyalahi dari aturan yang lazim, namun menurutnya itu yang terbaik.

b. Masalah Radd

Demikian juga dalam masalah radd, terjadi perbenturan antara melaksanakan ketentuan yang berlaku dengan keadaan yang berlaku dalam kenyataan sementara itu tidak ada petunjuk yang jelas dari pembuat hukum. Persoalan 'aul dan radd tidak ada aturan yang mengaturnya sehingga diserahkan kepada masing-masing pembuat kebijakan hukum atau mujtahid menyelesaikannya.

Masalah radd timbul karena adanya sisa harta sesudah dibagikan kepada dzul furudh, sedangkan ahli waris yang berhak tentang sisa harta tidak ada. Semua sisa harta yang ada dikembalikan kepada ahli waris $d z u l$ furudh yang ada berdasarkan kadar furudh masing-masing. Kalau furudhnya adalah $1 / 3$ dari harta makaradd yang diterimanya adalah sisa harta dari $1 / 3$ itu dan begitu seterusnya. Adapun tentang ketentuan dan cara pengambilan harta kepada furudh yang ada itu terdapat beberpa kebijakan hukum di kalangan ulama.

Kebijakan hukum yang diambil jumhur ulama adalah bahwa sisa harta yang ada diserahkan kepada ahli waris $d z u l$ furudh yang ada disebabkan oleh hubungan rahim. Dengan demikian ahli waris furudh yang melalui sebab perkawinan tidak berhak menerima pengembalian. Asalan pembatasan ini adalah karena yang menjadi alasan adanya radd tersebut adalah hubungan rahim sedangkan suami atau isteri kewarisannya adalah tersebab hukum dan bukan karena hubungan rahim. ${ }^{19}$

Adapun Usman bin Affan mengemukakan kebijakan hukum yang berbeda dengan jumhur ulama, bahwa pengembalian yang bernama radd itu berlaku juga untuk hubungan perkawinan sehingga semua ahli waris furudh mendapat hak atas radd. Menurut mereka alasan pembatasan yang dikemukakan jumhur

${ }^{19}$ Ibn Qudamah, Ibn Qudamah, al-Mughni, (Dar Ihya'al-Turats al-Arabiy,1985), Cet.ke-1, Jil.4, hlm.296 
ulama itu tidak kuat. Mereka menerima hak yang sama dalam pengurangan waktu terjadi ' $a u l$, tentu tidak ada alasan untuk membedakannya pada waktu menerima kelebihan hak. Alasan jumhur ulama tidak memberikan hak dalam bentuk radd kepada ahli waris yang disebabkan hubungan perkawinan, dianggap argumen yang lemah, yaitu bahwa apa yang diterima suami itu bukan dari kelebihan harta warisan tetapi dari baitul maal atau sabagai 'ashabah karena ada tambahan hubungan kekerabatan lain.

Sedangkan dalam kebijakan hukum yang diambil Ibn Mas'ud memberikan batasan adanya ahli waris yang tidak berhak atas pengembalian radd itu yaitu anak perempuan dari anak laki-laki waktu bersama anak perempuan; saudara perempuan seayah bila bersama saudara perempuan kandung; dan nenek pada saat bersama dengan orang yang punya saham. Diriwayatkan dari Ibn Mansur dari Ahmad bahwa saudara seibu tidak menerima radd kalau bersama ibu begitu pula kakek bila bersama yang punya saham. ${ }^{20}$

Bila diperhatikan perbedaan kebijakan hukum yang dikemukakan oleh sahabat sehubungan dengan persoalan radd ini jelas bahwa pertimbangan dalam kebijakan hukum yang dikemukakan Usman cukup jelas yaitu tidak membedakan ahli waris dalam penerimaan tambahan sebagaimana tidak dibedakan kewajiban menanggung kekurangan harta dalam ' 'aul. Pembatasanpembatasan yang dikemukakan Ibn Mas'ud dan Ibn Mansur tidak ditemukan alasan rasional atas pendapat ini, sehingga dengan demikian tidak dapat dijadikan argumen. ${ }^{21}$

Permasalahan yang terjadi dalam radd, sama dengan halnya dengan masalah yang terjadi dalam 'aul. Adanya ahli waris yang menerima haknya tidak sesuai dengan furudh yang semestikan, Jika dalam 'aul ahli waris mendapatkan furudh kurang dari yang seharusnya mereka terima, sementara dalam radd ahli waris mendapatkan furudh melebihi dari hak yang semestinya diterima. Dalam persoalan 'aul, kebijakan hukum yang diambil Umar ketika terjadinya perbenturan antara prinsip "melaksanakan tuntutan hukum" dengan prinsip "keadilan menurut keadaan yang berlaku dalam kenyataan" dianggap sebagai sebuah kebijakan hukum untuk mendapatkan kemashlahatan yang paling tinggi. Sedangkan dalam

\footnotetext{
${ }^{20}$ Ibid. hlm. 296

${ }^{21}$ Amir Syarifuddin, Op.cit., hlm.71
} 
masalah radd, pengembalian harta kepada ahli waris juga merupakan sebuah kebijakan hukum yang diambil ketika terjadinya kelebihan harta dalam pembagian warisan. Hanya saja, antara jumhur ulama dan Usman bin Affan berbeda dalam hal kepada siapa disalurkan kelebihan harta tersebut. Perbedaan ini disebabkan karena berbedanya dalam menetapkan pembatasan ahli waris yang berhak menerima radd.

2. Kebijakan hukum karena adanya perbenturan antara melaksanakan suatu ketentuan dengan ketentuan lain yang berbeda dengan itu

Adanya perbenturan antara melaksanakan suatu ketentuan dengan ketentuan yang lain yang berbeda juga dapat menimbulkan sebuah kebijakan hukum yang dapat menjadi solusi dan jembatan untuk menyelesaikan perbenturan tersebut. Di antara persoalan kewarisan yang dapat dijadikan contoh kasus dalam hal ini adalah kebijakan hukum dalam penyelesaian persoalan masalah Musyarakah ${ }^{22}$

Dalam konteks ini yang dimaksud musyarakah adalah apabila di dalam pembagian warisan terdapat dalam suatu kasus bahwa saudara sekandung (tunggal atau jamak) sebagai ahli waris ashabah tidak mendapatkan bagian harta sedikitpun, kerena telah dihabiskan ahli waris $d z u l$ furudh, yang di antaranya adalah saudara-saudara seibu.

Dalam ketentuan hukum yang terdapat dalam surat an-Nisa' ayat 12, saudara seibu memiliki hak waris $1 / 6$ atau 1/3. Namun dalam kasus musyarakah ini di samping saudara seibu itu kebetulan dalam susunan ahli waris itu ada saudara kandung laki-laki yang berdasarkan ketentuan dalam hadis Nabi SAW saudara kandung laki-laki berkedudukan sebagai ashabah. Dengan mengikuti ketentuan saudara kandung sebagai ashabah maka saudara kandung dalam susunan ahli waris seperti ini tidak mendapatkan hak apa-apa karena sisa harta tidak ada. Adapun saudara seibu mendapatkan hak karena furudhnya jelas berdasarkan ketentuan furudhnya. Inilah yang dinamakan dengan perbenturan antara memenuhi ketentuan ashabah dengan memenuhi ketentuan furudh. Dalam bentuk ini, ketentuan furudh dengan ketentuan ashabah berbenturan.

Lebih konkrit lagi akan diuraikan secara jelas bentuk dari persoalan musyarakah ini. Masalah musyarakah timbul karena

${ }^{22}$ Ada juga yang menyebut masalah ini dengan masalah musyarrikah dan musytarakah. Musyarrikah secara bahasa berarti berserikat, maksudnya adalah serikat antara dua orang atau lebih dalam suatu hal atau urusan. 
terdapatnya benturan antar prinsip memenuhi ketentuan furudh dengan prinsip memenuhi ketentuan ashabah, sekalipun secara pembagian harta warisan, telah dilaksanakan sesuai dengan petunjuk nash. Hal ini terjadi jika ahli waris terdiri dari suami, ibu, beberapa orang saudara seibu dan beberapa orang saudara laki-laki kandung. Berdasarkan petunjuk al-Qur'an suami menerima $1 / 2$, ibu $1 / 6$, beberapa saudara seibu 1/6 dan beberapa saudara laki-laki kandung sebagai ashabah. Setelah dijumlahkan furudh yaitu $1 / 2+1 / 6+1 / 6=3 / 6+1 / 6+1 / 6=6 / 6$, harta habis terbagi dan saudara laki-laki kandung sebagai ashabah tidak mendapatkan apa-apa. Masalah yang timbul di sini, kenapa saudara laki-laki kandung yang dianggap lebih utama dan kuat hubungan kekerabatanya dengan pewaris tidak mendapatkan apa apa sementara saudara seibu yang selama ini di anggap rendah mendapatkan bagian? Akar permasalahan yang terdapat dalam persoalan ini adalan benturan prinsip menjalankan faraid sesuai dengan tuntutan al-Qur'an dan prinsip saudara kandung harus lebih utama dari saudara seibu dalam kewarisan maupun dalam pembagian hak. Hal ini tampaknya masih dipengaruhi oleh adat jahiliyah yang tidak mengganggap saudara seibu yang pertalian kekerabatannya hanya dari seorang perempuan itu sebagai saudara yang berhak.

Kasus seperti ini dua kali dihadapkan kepada Umar bin alKhattab. Pada mulanya Umar bin al-Khattab menyelesaikan masalah tersebut menurut ketentuan al-Quran seperti contoh di atas. Kebijakan Umar itu diterima pihak yang bersangkutan meskipun mungkin ada rasa tidak puas. Pada waktu masalah yang sama kembali muncul dan dihadapkan kembali kepada Umar ternyata di antara saudara kandung ada yang protes dan tidak terima tidak mendapatkan warisan apapun. Mereka mengatakan :

$$
\text { يا أمير المؤمنين هب ان أبانا كان حمار ألسنا من أم واحدة ؟ }
$$

“Wahai Amir al-Mukminin, andaikata ayah kami adalah himar bukankah kami ini berasal dari ibu yang satu.? ${ }^{23}$,

Pada kasus pertama Umar bin al-Khattab keberatan mengabulkan tuntutan saudara sekandung dan mereka kembali dengan tangan kosong. Namun dalam kasus kedua mereka tidak puas dengan alasan yang sama, apabila ayah mereka himar atau dianggap bapaknya batu mereka juga mempunyai hubungan kekerabatan yang sama dengan

\footnotetext{
${ }^{23}$ Muhammad Syarbainy Khathib, Mughni al-Muhtaj, (Kairo: Musthafa al-Babiy alHalabiy, 1958), Juz.3, hlm.18
} 
saudara seibu. Logika dan argumentasi ini kemudian diterima oleh Umar dan diizinkan untuk berbagi sama banyak dengan saudarasaudara seibu. Inilah yang menjadi penyebab masalah ini dinamakan dengan musyarrikah karena saudara kandung digabung dengan saudara seibu. Juga disebut dengan himariyah dan hajariyah karena dalam argumen itu ayah disamakan dengan himar dan batu.

Kebijakan hukum yang diambil Umar, kemudian diikuti oleh Usman dan Zaid bin Tsabit memberi bagian dengan cara berbagi sama banyak saudara sekandung dan sudara-saudara seibu ini kemudian juga diikuti oleh Imam Malik, al-Syafi'i dan Ishak bin Rawaih. Mereka mengemukakan alasan bagian saudara-saudara sekandung itu identik dengan bagian saudara-saudara seibu disebabkan adanya persamaan hubungan kekerabatan dari satu sisi. Saudara-saudara kandung itu bersama-sama dengan saudara seibu dalam kekerabatan hubungan seibu dan oleh karena itu mereka juga bersama-sama dalam kewarisan. Adanya kelebihan kekerabatan pada saudara kandung yaitu hubungan seayah dibandingkan dengan saudara seibu, tidak pantas menggugurkan hak warisan itu. ${ }^{24}$

${ }^{24}$ Ibn Qudamah, Op.cit., hlm. 279-280. Namun ada segolongan sahabat yang tidak sependapat dengan pendapat Umar tersebut. Di antaranya Ali bin Abi Thalib, Ibnu Mas'ud, Ibn Abbas dan Ubay bin Ka'ab yang berpendapat bahwa saudara-saudara kandung itu tidak dapat berbagi sama banyak dengan saudara-saudara seibu dalam menerima bagian sepertiga. Saudara laki-laki gugur dari hak kewarisan sebagai ashabah karena harta sudah terbagi di kalangan $d z u l$ furudh dan tidak digabung bersama saudara seibu. Alasan mereka adalah menurut kesepakatan ulama bagian saudara seibu telah ditentukan bagiannya dalam al-Quran Surat Al-Nisa' ayat 12. Dalam hal ini ditetapkan furudh saudara seibu yaitu 1/6 kalau sendirian dan $1 / 3$ untuk bersama-sama kalau terdiri dari dua orang atau lebih. Kalau saudara kandung digabungkan dengan mereka maka saudara seibu tidak akan menerima furudh sesuai dengan yang ditetapkan dalam ayat itu. Di lain pihak saudara kandung diatur dengan ayat 176 surat al-Nisa'. Seandainya ia lakilaki maka ia akan menjadi ahli waris sebagai ashabah. Kalau digabungkan dengan saudara seibu untuk mendapatkan yang $1 / 3$ itu akan berubah kedudukannya menjadi $d z u l$ furudh. Dengan alasan ini tidak ada alasan bagi saudara sekandung bergabung dengan saudara seibu. Mengubah bagian saudara seibu berarti mengubah ketentuan Allah. Ulama tersebut sangat literalis dan sangat tekstual dalam memahami ketentuan ayat. Di kalangan Imam mazhab yang mendukung pendapat Ali ini adalah Imam Hanafi, Ahmad bin Hanbal, Abu Tsaur, al-Sya'bi, al-Munzir dan Ibnu Qudamah. Ulama yang terakhir ini mengatakan bahwa cara penyelesaian yang ditempuh Ali secara lahiriah sesuai dengan nash. 
Jika diperhatikan lagi dengan cermat akan tampak akar permasalahan ini adalah benturan antara prinsip menjalankan faraidh sesuai dengan tuntutan al-Quran dan prinsip ketentuana saudara kandung sebagai ashabah harus lebih utama dari saudara seibu dalam kewarisan maupun dalam pembagian hak, jangan sampai terjadi kebalikannya. Kebijakan yang dilakukan Umar bin Khattab dalam masalah musyarakah ini adalah kebijakan yang didasarkan kepada keadilan. Dengan alasan yang logis dan rasional yang dikemukakan oleh saudara kandung, Umar mengupayakan agar adanya keadilan di antara ahli waris yang mendapat warisan. Jika dinafikan hak saudara seibu dengan melihat hubungan kekerabatan saudara kandung lebih kuat dan lebih berhak, akan sulit juga memahami lafaz saudara dalam surat al-Nisa' ayat 12. Di lain pihak, jika harta tidak diberikan kepada saudara kandung yang berhak menerima sisa sebagai ashabah karena harta telah habis untuk $d z u l$ furudh, artinya Umar bin al-Khattab tidak memberikan keadilan kepada saudara kandung yang memiliki hubungan kekerabatan lebih kuat dari saudra seibu. Adanya perbenturan melaksanakan nash dengan prinsip keadilan inilah yang menyebabkan munculkan keputusan dari Umar berupa kebijakan hukum yang dapat memuaskan semua pihak.

3. Kebijakan hukum ketika terjadinya perbenturan melaksanakan ketentuan hukum dengan rasa keadilan masyarakat

Di antara dasar adanya kebijakan hukum adalah karena pertimbangan antara melaksanakan ketentuan hukum dengan rasa keadilan masyarakat. Ketika rasa keadilan masyarakat menghendaki seperti ini sementara ketentuan hukum tidak berbicara sepeti itu maka pada saat itulah timbulnya perbenturan yang mengharuskan adanya sebuah solusi hukum. Rasa keadilan masyarakat itu didasari oleh adat istiadat yang berlaku. Dalam penyelesaian kewarisan Islam dapat dicontohkan seperti penyelesaian masalah gharrawain, al-kharqa' dan akdariyah.

Masalah gharrawain ${ }^{25}$ ini terjadi ketika penjumlahan beberapa furudh dalam satu kasus kewarisan yang hasilnya tidak memuaskan

${ }^{25}$ Secara bahasa gharrawain berasal dari kata gharra artinya menipu. Ulama lain mengartikan gharrawain adalah bentuk ganda (tatsniyah) dari kata gharr yang artinya cemerlang seperti bintang. Disebut demikian karena masalah ini cemerlang bagaikan bintang. Ada istilah lain yang digunakan oleh ulama dalam penamaan masalah ini, yaitu umariyatani dan al-gharibaini. 
beberapa pihak. Hal ini terjadi ketika ahli waris terdiri dari ayah, ibu dan salah seorang suami/ isteri. Ketika diselesaikan dengan cara memberikan hak ahli waris sesuai dengan apa yang terdapat dalam nash, ternyata ayah mendapatkan bagian yang kurang dari ibu, sehingga bagian ibu yang seharusnya sepertiga harta (تلث المال) ditakwilkan menjadi sepertiga sisa (تلث الباقى). Penakwilan bagian ibu menjadi seperti sisa itu disebabkan karena mengharuskan bagian lakilaki itu dua kali dari bagian perempuan dan rasa keadilam masyarakat ketika itu yang menempatkan ayah dalam posisi yang tidak boleh kurang bagiannya dari ibu. Sementara dalam al-Qur'an hanya menjelaskan bagian ibu itu sepertiga atau seperenam dari harta. ${ }^{26}$ Bentuk penyelesaian masalah ini dapat dilihat dalam contoh kasus berikut :

Dalam contoh kasus pertama (Umariyah I), susunan ahli waris: suami, ibu dan ayah. Dalam susunan ahli waris seperti ini, menurut petunjuk al-Qur'an suami menerima $1 / 2$, ibu menerima $1 / 3$ dan ayah sebagai ashabah. Ketika dijumlahkan furudh suami dan ibu, keduanya menerima $1 / 2+1 / 3=3 / 6+2 / 6=5 / 6$, sehingga sisa harta menjadi $1 / 6$. Sebagai ashabah maka $1 / 6$ itu menjadi hak ayah. Cara seperti ini adalah menurut petunjuk al-Qur'an dan sunnah dan tidak ada masalah dalam penyelesainnya. Namun, ketika membandingkan bagian ayah dengan ibu ternyata bagian ibu lebih besar dari ayah, sehingga dirasa ada kejanggalan jika ibu menerima dua kali ayah karena menurut biasanya bagian laki-laki itu dua kali perempuan. Dalam mengatasi masalah ini Umar bin al-Khattab memahami bagian ibu 1/3 itu bukan dari harta tapi dari sisa setelah dikeluarkan hak suami. Sehingga dalam pembagiannya suami $1 / 2$ atau $3 / 6$, ibu $1 / 3 \times 1 / 2=1 / 6$ dan ayah sebagai ashabah mendapatkan bagian 2/6. Hasil akhir ini tampaknya sesuai dengan kaidah yang selama ini berlaku bahwa laki-laki menerima dua kali perempuan. Selanjutnya kebijakan hukum ini digunakan Umar dalam memutus kasus ini yang kemudian diikuti oleh para sahabat seperti Zaid, Usman,Ibn Mas'ud dan juga diriwayatkan dari Ali. Begitupun jumhur ulama mujtahid.

Alasan yang dikemukakan untuk memahami $1 / 3$ hak ibu menjadi $1 / 3$ sisa adalah untuk menghindari lebih besarnya hak ibu ketimbang 
hak ayah. Bahkan Ibn Qudamah dalam bukunya menyatakan bahwa tidak diperbolehkan hak ibu lebih besar dibanding hak ayah. ${ }^{27} \mathrm{Di}$ samping itu mereka memperkuat alasan ini dengan pernyataan Ibn Mas'ud yang diriwayatkan oleh Sofyan al-Tsauri: "Allah tidak memperlihatkan kepada saya kelebihan ibu daripada ayah". ${ }^{28}$

Ibn Abbas merupakan salah seorang sahabat yang tidak menyetujui kebijakan yang diambil Umar tersebut. Menurutnya, ibu dalam kasus ini tetap menerima $1 / 3$ dari keseluruhan harta sesuai dengan zahir ayat al-Qur'an surat an-Nisa ayat 11: "Jika ia tidak meninggalkan anak dan ia diwarisi oleh orangtuanya maka untuk ibu sepertiga". Sedangkan hak ayah sesuai dengan hadis Nabi SAW yang berbunyi: "Berikanlah faraid (bagian-bagian yang ditentukan) itu kepada yang berhak dan selebihnya berikanlah untuk laki-laki dari keturunan laki-laki yang terdekat. (HR.Bukhari)

Dalam persoalan ini karena ayah merupakan satu-satu ahli waris laki-laki terdekat melalui garis laki-laki, maka ayah menempati posisi sebagai ashabah dan menerima sisa harta 1/6. Menurut Ibn Abbas, tindakan yang dilakukan di luar ketentuan tersebut menyalahi petunjuk Allah SWT dan Rasulullah SAW. Imam Mujhatid yang mengikuti kebijakan hukum yang dikemukakan oleh Ibn Abbas ini adalah Daid Zahiri. Ibn Hazm yang mengikuti aliran Zahiriyah, membela Ibn Abbas dan menangkis kebijakan yang dikemukakan oleh Jumhur ulama. ${ }^{29}$ Keberatan Jumhur menerima hak ibu lebih besar dari ayah ini disanggah oleh golongan Zahiri dengan mengemukakan hadis Nabi yang mengeaakan bahwa yang paling berhak menerima pengkhidmatan iu adalah ibu (sebanyak tiga kali). Hadis ini menolak apa yang diriwayatkan Ibn Mas'ud sebelumnya.

Dalam contoh kasus kedua (Umariyah II): Masalah ini sebenarnya sama dengan masalah umariyah I yang dijelaskan sebelumnya, hanya berbeda dalam susunan ahli waris. Kalau pada masalah Umariyah I ahli waris terdiri dari ayah dan ibu didamping oleh suami, di sini ayah dan ibu di dampingi oleh isteri. Kebijakan hukum yang diambil oleh Ibn Abbas tetap tidak sama dengan kebijakan hukum yang dikemukakan oleh Umar dan sahabat yang lain.

\footnotetext{
${ }^{27}$ Ibn Qudamah, Op.cit., hlm. 279

${ }^{28}$ Amir Syarifuddin, Op.cit.,hlm. 72

${ }^{29}$ Ibn Hazm, Op.cit.,Jil.10, hlm. 326-330
} 
Dalam kasus ini berdasarkan petunjuk al-Qur'an, isteri menerima furudh sebanyak 1/4 karena pewaris tidak meninggalkan anak, ibu menerima furudh $1 / 3$ karena pewaris tidak meninggalkan anak dan beberapa saudara. Setelah dijumlahkan furudh mereka, 1/4+1/3= $3 / 12+4 / 12=7 / 12$. Ayah sebagai ashabah akan mendapatkan sisa 5/12. Jumhur ulama tetap mengambil sebuah kebijakan hukum dengan memahami furudh ibu 1/3 yang disebutkan al-Qur'an itu sebagai $1 / 4$ sisa harta sebagaimana bila ayah dan ibu itu didampingi oleh suami.

Berdasarkan kebijakan hukum Jumhur ini ibu mendapat 1/3 dari $3 / 14$ (sisa setelah diambil hak isteri) menjadi $1 / 4$. Bila isteri mendapat $1 / 4$ dan ibu juga mendapat 1/4 maka ayah sebagai ahli waris ashabah mendapat $1 / 2$. Dengan cara begini hak ayah menjadi dua kali bagian ibu.

Sedangkan Ibnu Abbas tetap dengan pendirian awal bahwa ibu menerima 1/3 dari seluruh harta dan bukan dari sisa harta sesuai dengan petunjuk yang jelas dari nash al-Qur'an, sehingga berdasarkan pendiriannya itu Ibn Abbas mengemukakan kebijakan hukum dalam masalah ini dengan memberikan hak ayah sebagai ashabah yang berhak menerima sisa harta setelah diberikan hak untuk furudh yang ada sebesar 5/12. Kebijakan hukum ini diambil oleh Ibn Abbas dengan berpegang kepada ketentuan nash yang ada tanpa terpengaruh oleh keharusan bagian ayah mesti melebihi atau dua kali bagian ibu.

Berbeda dengan dua kebijakan hukum di atas, Ibu Siirin sebagai ulama yang mencoba mengambil jalan tengah dari dua bentuk kebijakan hukum tersebut, mengikuti kebijakan hukum yang dikemukakan oleh Jumhur ulama untuk menjadikan hak ibu dari 1/3 menjadi $1 / 3$ sisa dalam kasus ahli waris adalah ayah dan ibu bersama suami dan mengikuti kebijakan hukum yang diambil oleh Ibnu Abbas dengan memahami hak ibu yang $1 / 3$ itu dalam arti $1 / 3$ keseluruhan harta dalam kasus ahli waris adalah ayah dan ibu bersama isteri. Hal seperti ini diamalkan oleh Abu Tsaur. ${ }^{30}$

Dalam penyelesaian masalah di atas terlihat bahwa kebijakan hukum yang dikemukakan oleh Jumhur ulama tampaknya menginginkan hak ayah itu lebih besar dari ibu, bahkan mesti dua kali bagian ibu sebagaimana yang berlaku bagi anak laki-laki ketika mewarisi bersama anak perempuan dan saudara laki-laki kandung atau

\footnotetext{
${ }^{30}$ Ibn Hazm, Op.cit. hlm. 279
} 
seayah ketika mewarisi bersama saudara perempuannya. Sedangkan Ibn Siirin tidak mengharuskan bandingan bagian ayah itu dua kali bagian ibu, tetapi mesti melebihi bagian ibu. Sehingga dalam kasus kedua tidak perlu menakwilkan ayat al-Qur'an. Berbeda halnya dengan Ibn Abbas yang tetap bersikukuh untuk memahami ayat al-Qur'an menurut zahirnya.

Apabila dianalisa persoalan di atas, agaknya kebijakan hukum yang diambil Umar bin al-Khattab yang diikuti oleh Jumhur ulama terjadi ketika adanya perbenturan antara tuntutan menjalani al-Qur'an menurut zahirnya dengan rasa keadilan masyarakat Arab ketika itu yang mengharuskan laki-laki melebihi dari perempuan dalam penerimaan hak waris. Bahkan dengan berpedoman kepada bandingan laki-laki mendapatkan hak dua kali perempuan dalam surat al-Nisa' ayat 11 , nampaknya pemahaman laki-laki dalam ayat tersebut bukan saja berlaku bagi anak dan saudara. Ayahpun termasuk salah satu dalam kata laki-laki yang disebutkan dalam ayat. Hal ini dapat dipahami dari kebijakan Umar yang diikuti oleh Jumhur ulama, yang mengharuskan bagian ayah itu dua kali bagian ibu ketika mewarisi bersama suami atau isteri.

Masih banyak masalah kewarisan lain yang diselesaikan melalui kebijakan yang diambil oleh Umar bin al-Khattab, seperti masalah kewarisan kakek bersama saudara yang menimbulkan masalah lebih rumit lagi karena mempertimbangkan hak kakek yang mesti mendapatkan hak waris yang menguntungkan (seperti dalam masalah akdariyah dan al-kharqa'. Demikian juga dalam persoalan kewarisan bayi dalam kandungan dan orang mafqud, banyak kebijakan hukum yang timbul dan dipakai dalam menyelesaikan persoalan ini karena nash yang berbicara secara langsung tentang masalah ini tidak ada, sehingga untuk menyelesaikannya diselesaikan melalui ijtihad atau kebijakan hukum.

Adanya beberapa kebijakan yang dibuat oleh Umar bin al-Khattab dalam menyelesaikan masalah kewarisan, terlihat memiliki pertimbangan hukum yang berbeda antara satu dengan yang lainnya. Umar bin al-Khattab berani mengambil suatu kebijakan hukum yang didasarkan kepada ijtihadnya karena tidak adanya nash baik al-Quran atau hadis Nabi SAW yang menjelaskan masalah tersebut. Dari satu sisi, kebijakan hukum yang diambil oleh Umar bin al-Khththab adalah sebuah solusi hukum untuk menyelesaikan masalah pembagian 
warisan seperti dalam kasus ' $a u l$ dan radd karena jika tidak dilakukan 'aul dan radd maka pembagian harta warisan tidak bisa diselesaikan. Cara tersebut mesti ditempuh untuk menyelesaikan pembagian warisan. Berbeda halnya dalam masalah gharawain, musyarakah, akdariyah dan al-kharqa'. Dalam masalah ini, secara pembagian, harta warisan telah bisa dilaksanakan dan dibagikan kepada ahli waris yang berhak, tidak ada masalah yang timbul dalam pembagian jika dilakukan sesuai dengan ketentuan nash yang ada. Masalah yang timbul dalam kasus-kasus ini hanyalah rasa keadilan yang belum terpenuhi menurut perasaan mujtahid ketika itu. Rasa keadilan yang dimkasudkan adalah untuk ahli waris laki-laki yang mendapatkan hak waris lebih sedikit dari perempuan. Agaknya, perasaan dan kebijakan hukum yang dilakukan Umar bin al-Khattab ini, masih dipengaruhi oleh wajah arab jahiliyah dahulu yang tidak dapat menerim hak waris perempuan melebihi ahli waris laki-laki. Wajah arab inilah yang masih muncul dalam beberapa masalah penyelesaian kearisan dalam Islam.

\section{PENUTUP}

Beberapa kebijakan hukum yang dibuat oleh ulama sahabat seperti Umar bin al-Khattab dalam menyelesaikan persoalan kewarisan, memiliki pertimbangan hukum yang beragam. Terjadinya perbenturan antara tuntutan suatu ketentuan dengan keadaan yang berlaku menurut kenyataan, adanya perbenturan melaksanakan suatu ketentuan dengan ketentuan lain yang berbeda dengan itu dan perbenturan yang terjadi nantra ketentuan hukum dengan rasa keadilan menurut mmasyarakat.

Dalam menyelesaian pembagian warisan dalam Islam dapat ditempuh kebijakan hukum selama kemashlahatan menghendakinya dan tidak menyalahi dalil-dalil yang qath' $i$ dalam al-Qur'an dan Hadis Ada yang tetap besikukuh menjalankan prinsip "melaksanakan tuntutan hukum" seperti apa yang terdapat dalam nash tanpa terpengaruh oleh "rasa keadilan menurut masyarakat" tertentu. Ada juga yang mencoba merubah ketentuan yang telah ditetapkan dengan pertimbangan "rasa keadilan masyarakat" terhadap ahli waris tertentu sehingga menawarkan cara penyelesaian yang berbeda menurut lazimnya.

Bentuk kebijakan hukum yang pernah dibuat oleh Umar bin alKhattab sebagai pembuat hukum atau mujtahid adalah sebuah solusi 
untuk menjawab permasalahan yang timbul disebabkan adanya perbenturan antara ketentuan hukum dengan keadaan yang ada dalam kenyataan. Demikian juga halnya dalam penyelesaian beberapa persoalan kewarisan yang termasuk masalah ijtihadiyah, yang lebih bersifat tathbiqy (penerapan hukum) dan dalam penerapannya perlu memperhatikan dan mempertimbangkan nilai-nilai keadilan yang hidup dalam kesadaran hukum masyarakat di mana hukum tersebut dilaksanakan, juga memerlukan kebijakan hukum.

\section{DAFTAR PUSTAKA}

Abidin, Ibn. Hasyiyah Radd al-Mukhtar 'ala ad-Durr al-Muhtar Jilid VI. Mesir: Mustafa al-Babiy al-Halabiy, 1966.

Al-Bukhariy, Imam. Shahih al-Bukhariy Juz.IV. Beirut: Daar al-Kutub alIlmiyah, 1998.

Al-Zuhaily, Wahbah. Al-Fiqh al-Islamy wa Adillatuhu Juz 10. Damsyiq: Dar al-Fikr, 1997.

Departemen Pendidikan dan Kebudayaan. Kamus Besar Bahasa Indonesia cet ke 3. Jakarta: Balai Pustaka, 1990.

Hazm, Ibn. Aal-Muhalla Jilid X. Mesir: Mathba'ah al-Jumhuriyah, al'Arabiyah, 1970.

Persons, Wayne. Public Policy: Pengantar Teori dan Praktik Analisis Kebijakan Cet ke-5. Jakarta : Kencana, 2014.

Qudamah, Ibn. Al-Mughn I Cet ke-1 Jilid 4. Dar Ihya'al-Turats al-Arabiy, 1985.

Soekanto, Soerjono, dan Sri Mamudji. Penelitian Hukum Normatif: Suatu Tinjauan Singkat. Jakarta: PT. Rajagrafindo Persada, 1983.

Sudarsono. Kamus Hukum cet ke-4. Jakarta: Rineka Cipta, 2005.

Syarbainy, Khathib Muhammad. Mughni al-Muhtaj Juz.3. Kairo: Musthafa al-Babiy al-Halabiy, 1958.

Syarifuddin, Amir. Hukum Kewarisan Islam Edisi I Cet I. Jakarta: Kencana, Prenada Media, 2004. , Permasalahan dalam Pelaksanaan Faraid Cet ke-1.

Padang: IAIN IB Press, 1999. 